J. Perinat. Med. 17 (1989) 439

\section{Fetal abdominal circumference rather than fetal femur length/ abdominal circumference ratio predicts fetal malnutrition in high risk pregnancies}

\author{
Sten Petersen, Torben Larsen, and Gorm Greisen \\ University of Copenhagen, Department of Paediatrics, Glostrup Hospital, Glos- \\ trup, Department of Diagnostic Ultrasound and Department of Obstetrics and \\ Gynaecology, Herlev Hospital, Herlev, Denmark
}

\section{Introduction}

Birth weight (BW) below 10th percentile (smallfor-gestational age, SGA) is associated with poor postnatal growth and development, and the infants are at risk for neurological sequelae $[7,10]$. In the newborn, ponderal index (PI), skinfold thickness (ST) [1] and the clinical appearance of dysmaturity are signs of fetal malnutrition, and these parameters correlates with the body fat content as calculated from measurement of lean body mass [9]. Infants with PI below 10th percentile are shown to have increased perinatal morbidity [11].

Reliable methods for identification of intrauterine growth retardatin (IUGR) and distinction between fetuses with normal growth along a low percentile (symmetric growth retardation) and fetuses with decelerating growth velocity (asymmetric growth retardation) are important in monitoring intrauterine growth. Knowledge of gestational age (GA) is the basis for interpretation of most fetal measurements. However, HADLOCK et al. [4] found that fetal femur length (FFL)/abdominal circumference (AC) ratio was constant from 21 weeks and thereby independent of GA. This ratio was found useful for recognition of IUGR, and especially important in cases when GA was unknown.

The aim of this report is to establish reference data for AC and FFL/AC ratio and to compare these parameters in prediction of fetal growth retardation as indicated by BW deviation, PI, ST, and semiquantitative clinical estimation of

\section{Curriculum vitae}

Sten Petersen, M.D., was born in 1946 in Copenhagen, Denmark. After graduation from University of Copenhagen in 1972 he specialized in pediatrics in 1983. He is now a senior registrar at the Department of Neonatology, State University Hospital in Copenhagen. His main field of interest is perinatal growth and development.

dysmaturity in the newborn (dysmaturity score) in a prospective studied group of risk pregnancies.

\section{Material}

\subsection{Normal pregnancies}

In 35 pregnant women without obstetrical risk factors or complications and who delivered at term, sonographic measurements of biparietal diameter (BPD), FFL and AC were performed from 16 weeks of gestation and with two week intervals till birth. GA was calculated from the BPD of the first examination.

The infants, 22 boys and 13 girls, had a mean GA at birth of 282 days (SD 8.4 days), mean BW $3660 \mathrm{~g}$ (SD $560 \mathrm{~g}$ ), and mean crown-heel length $524 \mathrm{~mm}$ (SD $27 \mathrm{~mm}$ ). 
Normal fetal growth charts for boys and girls based on measurements in these patients are published elsewhere [5].

\subsection{Risk pregnancies}

From a prospective study of 500 high risk pregnancies [6] 350 patients who fulfilled the following criteria were included in this investigation: 1) GA could be obtained from measurement of BPD before 22 weeks, 2) delivery within the range of 259-293 days of gestation, 3) $\mathrm{AC}$ and FFL were measured within two weeks before birth, and 4) infants were seen by one of the authors for anthropometric measurements at birth.

The mean interval from ultrasonography to birth was 6.0 days. The clinical data of the infants, 159 boys and 191 girls, are presented in table I.

In 255 of the infants an examination 6-8 weeks before birth could be included to study the relation between individual changes in AC or FFL/ $\mathrm{AC}$ ratio and the clinical observations at birth.

\section{Methods}

GA was calculated from ultrasonographic assessment of the BPD before 22 weeks of gestation using the formula GA $=40.1+2.405 * \mathrm{BPD}$ $-0.015 * \mathrm{BPD}^{2}+0.000165 * \mathrm{BPD}^{3}$ [8]. The measuring techniques for BPD, AC and FFL are described elsewhere [5]. FFL/AC ratio was calculated as described by HADLOCK et al. [4] as FFL $* 100 /$ AC.

The newborn infant's crown-heal length was measured on a Harpenden infantometer, head circumference (greatest fronto-occipital circumference) with a calibrated measuring tape. Skinfolds were measured using a Harpenden skinfold caliper at five places (quadriceps, pectoralis, biceps, subscapular, and triceps) [12], and ST was expressed as the sum of these 5 measurements. PI was calculated as BW (gram) $\times 100 /$ crownheel length $(\mathrm{cm})^{3}$.

A semi-quantitative estimation of dysmaturity was based on the following clinical signs: 1) lean arms and legs, 2) lean trunk with skin lying in folds, 3) dry, cracking or parchment-like skin, and 4) cracking or peeling of skin in hands and feet. Points 0,1 or 2 was given for each sign when not present, slight or moderate, and pro- nounced, respectively. We considered infants with dysmaturity scores 4-8 markedly dystrophic.

Deviation (\%) of BW from the 50th percentile of the normal group was calculated for each infant. Infants were considered SGA when their $\mathrm{BW}$ was below the 10 th percentile $=$ weight deviation more than $-14.5 \%$. Infants were considered heavy-for-gestational age (HGA) when their BW was above the 90th percentile.

AC deviation from the mean value for GA of the normal group expressed in standard deviation scores (AC-SDS) was calculated as the difference between observed $\mathrm{AC}$ and expected $\mathrm{AC}$ for GA divided by the standard devidation for GA: $\mathrm{AC}-\mathrm{SDS}=($ observed $\mathrm{AC}-\operatorname{expected} \mathrm{AC}) /$ SD.

Statistical methods: T-test was used to test differences between mean values in subgroups, Fischer's exact test was used to test differences in $2 \times 2$ tables for discriminant analysis. The cut off levels were adjusted to select equal numbers of patients corresponding to about 1.5 times the actual prevalence. Linear regression analysis were used to test relations between variables, and weighted multiple polynomial regression (until 6th power) was used to fit $\mathrm{AC}$ to GA. The standard deviation of $\mathrm{AC}$ for each gestational week was linearly related to GA: SD of AC $=0.14 \mathrm{~mm}+0.415 \mathrm{~mm} *$ GA (in weeks). The weighting used in the regression was the reciprocal of SD. Accuracy of the methods was estimated from the sensitivity $=$ true positive/(true positive + false negative), the specificity $=$ true negative/(true negative + false negative), the positive predictive value $=$ true positive $/$ (true positive + false positive).

The study was approved by the local ethics committee.

\section{Results}

\subsection{Normal pregnancies}

The regression of AC on GA from 12 weeks till term was: $\mathrm{AC}=-81.0+1.70 * \mathrm{GA}$ $-5.66994 \mathrm{E}-9 * \mathrm{GA}^{4}, \mathrm{R}$-squared $=0.98, \mathrm{SEE}$ $=11.7 \mathrm{~mm}$.

A plot of 401 measurements of FFL/AC ratio is presented in figure 1. From 303 measurements after 146 days of gestation ( 21 completed weeks) 


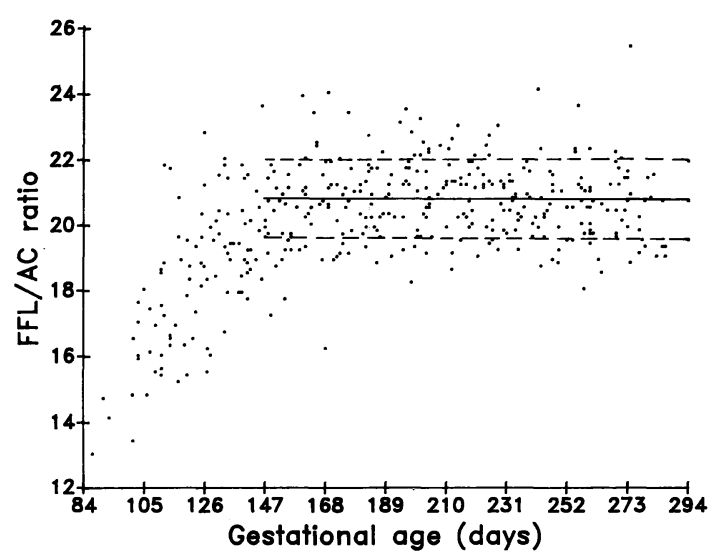

Figure 1. FFL/AC ratio by gestational age in 35 normal pregnancies. Mean $\pm \mathrm{SD}$ in the interval from 21 to 40 weeks of gestation.

we found mean $\mathrm{FFL} / \mathrm{AC}$ ratio $=20.9$, SD $=1.2$, and range $16.4-25.6$. The means of the 11-19 measurements for each gestational week in this period ranged from 20.2 to 21.4.

Regression analysis of FFL/AC ratio by GA after 146 days demonstrated the constancy: slope $=0.00010$ with $95 \%$ confidense interval from -0.00335 to 0.00355 .

The coefficient of variation was $7.0 \%$, when individual means were calculated the mean coefficient of variation around the individual mean values was much smaller: $4.5 \%$.

\subsection{Risk pregnancies}

FFL/AC ratio, AC-SDS, PI, ST, and dysmaturity score differed significantly among SGA, AGA and LGA infants (table I). Mean AC-SDS for each dysmaturity score is presented in figure 2. Both FFL/AC ratio and AC-SDS were significantly different in 36 infants with dysmaturity scores $4-8(\mathrm{FFL} / \mathrm{AC}=21.5, \mathrm{AC}-\mathrm{SDS}=-2.1)$ when compared with 314 with dysmaturity scores $0-3 \quad(\mathrm{FFL} / \mathrm{AC}=20.7, \quad$ AC-SDS $=-1.0)$, $\mathrm{p}$ values $<0.001$.

The correlation between AC-SDS and deviation of $\mathrm{BW}$ from 50th percentile was significant $(\mathrm{p}<0.001)$, correlation coefficient $=0.76$, $R$ squared $=57.0 \%$ (figure 3 ), whereas the correlation between FFL/AC ratio and the deviation of BW from the normal 50th percentile though

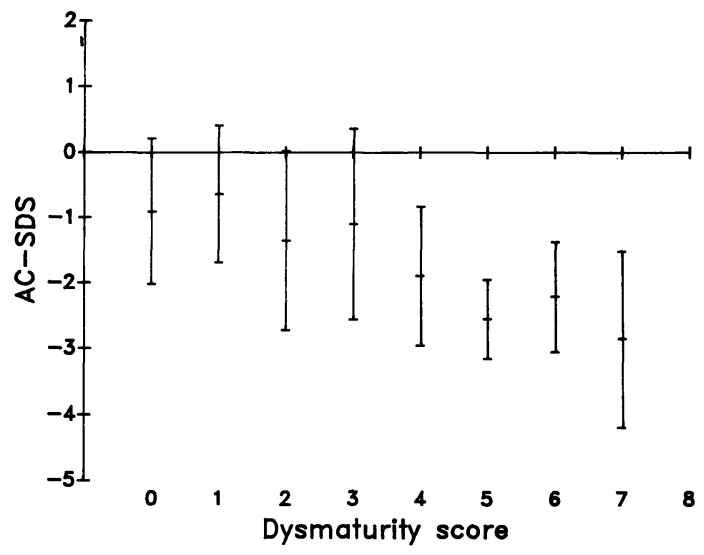

Figure 2. Mean $\pm \mathrm{SD}$ of AC standard deviation score (AC-SDS) for each dysmaturity score in 350 risk pregnancies.

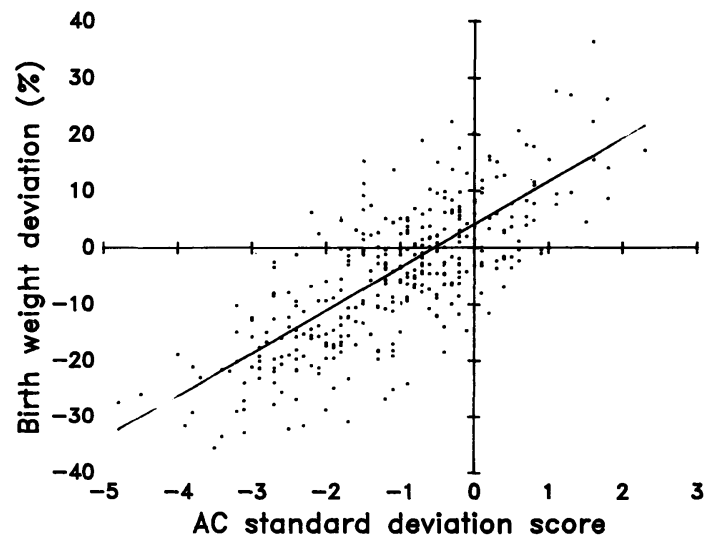

Figure 3. Regression of BW deviation from normal by AC standard deviation score (AC-SDS) in 350 risk pregnancies.

also significant $(\mathrm{p}<0.001)$ was weaker: correlation coefficient $=-0.37, \quad \mathrm{R}$-squared $=13.9 \%$.

The correlation between AC-SDS and PI was significant $(\mathrm{p}<0.001)$ with correlation coefficient $=0.53$ and $\mathrm{R}$-squared $=27.8 \%$, whereas the correlation between FFL/AC ratio and PI though significant $(p<0.001)$ had lower correlation coefficient $(-0.45)$ and R-squared $(20.7 \%)$.

The correlation between AC-SDS and ST was significant $(\mathrm{p}<0.001)$ with correlation coefficient $=0.52$ and $\mathrm{R}$-squared $=27.4 \%$, whereas 
Table I. Clinical data in 350 term infants from risk pregnancies

\begin{tabular}{|c|c|c|c|}
\hline $\begin{array}{l}\text { Number of infants } \\
\%\end{array}$ & $\begin{array}{l}\text { SGA } \\
77 \\
22.0\end{array}$ & $\begin{array}{l}\text { AGA } \\
250 \\
71.4\end{array}$ & $\begin{array}{l}\text { LGA } \\
23 \\
6.6\end{array}$ \\
\hline \multicolumn{4}{|l|}{ FFL/AC ratio } \\
\hline $\begin{array}{l}\text { Mean } \\
\text { SD }\end{array}$ & $\begin{array}{c}21.6^{*} \\
1.4\end{array}$ & $\begin{array}{r}20.6 \\
1.2\end{array}$ & $\begin{array}{c}20.1^{\mathrm{a}} \\
1.2\end{array}$ \\
\hline \multicolumn{4}{|l|}{ AC-SDS } \\
\hline $\begin{array}{l}\text { Mean } \\
\text { SD }\end{array}$ & $\begin{array}{c}-2.4^{*} \\
0.8\end{array}$ & $\begin{array}{r}-0.8 \\
0.9\end{array}$ & $\begin{array}{l}0.5^{*} \\
1.0\end{array}$ \\
\hline \multicolumn{4}{|l|}{$\mathrm{AC}$} \\
\hline $\begin{array}{l}\text { Mean (mm) } \\
\text { SD (mm) }\end{array}$ & $\begin{array}{l}314^{*} \\
16\end{array}$ & $\begin{array}{r}343 \\
18\end{array}$ & $\begin{array}{c}366^{*} \\
19\end{array}$ \\
\hline \multicolumn{4}{|l|}{ Gestational age } \\
\hline $\begin{array}{l}\text { Mean (days) } \\
\text { SD (days) }\end{array}$ & $\begin{array}{c}275^{\circ} \\
8\end{array}$ & $\begin{array}{r}277 \\
7\end{array}$ & $\begin{array}{c}278^{\circ} \\
9\end{array}$ \\
\hline \multicolumn{4}{|l|}{ Birth weight } \\
\hline $\begin{array}{l}\text { Mean }(g) \\
\text { SD }(g)\end{array}$ & $\begin{array}{l}2668^{*} \\
250\end{array}$ & $\begin{array}{r}3396 \\
331\end{array}$ & $\begin{array}{l}4145^{*} \\
332\end{array}$ \\
\hline \multicolumn{4}{|l|}{ Crown-heel length } \\
\hline $\begin{array}{l}\text { Mean }(\mathrm{mm}) \\
\mathrm{SD}(\mathrm{mm})\end{array}$ & $\begin{array}{c}475^{*} \\
17\end{array}$ & $\begin{array}{r}501 \\
15\end{array}$ & $\begin{array}{l}519^{*} \\
17\end{array}$ \\
\hline $\begin{array}{l}\text { Neonatal abdominal circumfere } \\
\text { Mean }(\mathrm{mm}) \\
\text { SD }(\mathrm{mm})\end{array}$ & $\begin{array}{c}289^{*} \\
37\end{array}$ & $\begin{array}{r}318 \\
26\end{array}$ & $\begin{array}{c}344^{*} \\
17\end{array}$ \\
\hline $\begin{array}{l}\text { Neonatal head circumference } \\
\text { Mean }(\mathrm{mm}) \\
\text { SD }(\mathrm{mm})\end{array}$ & $\begin{array}{c}333^{*} \\
10\end{array}$ & $\begin{array}{r}346 \\
11\end{array}$ & $\begin{array}{c}359^{*} \\
11\end{array}$ \\
\hline $\begin{array}{l}\text { Ponderal index } \\
\text { Mean } \\
\text { SD }\end{array}$ & $\begin{array}{l}2.49^{*} \\
0.17\end{array}$ & $\begin{array}{l}2.70 \\
0.17\end{array}$ & $\begin{array}{l}2.97^{*} \\
0.24\end{array}$ \\
\hline $\begin{array}{l}\text { Skinfold thickness } \\
\text { Mean }(\mathrm{mm}) \\
\text { SD }(\mathrm{mm})\end{array}$ & $\begin{array}{c}18.0^{*} \\
2.8\end{array}$ & $\begin{array}{r}21.9 \\
3.0\end{array}$ & $\begin{array}{c}25.6^{*} \\
2.9\end{array}$ \\
\hline Dysmaturity score $0-3 \mathrm{n}(\%)$ & $54 \quad(70 \%)$ & $237(95 \%)$ & $23(100 \%)$ \\
\hline Dysmaturity score $4-8 \mathrm{n}(\%)$ & $23(30 \%)$ & $13 \quad(5 \%)$ & 0 \\
\hline
\end{tabular}

T-test was used to test differences between means:

o) n.s. when compared to AGA

a) $\mathrm{p}<0.05$ when compared to AGA

*) $\mathrm{p}<0.001$ when compared to AGA

the correlation between FFL/AC ratio and ST was significant $(\mathrm{p}<0.001)$ but weak: correlation coefficient $=-0.30$ and $\mathrm{R}$-squared $=9.0 \%$.

Using AC-SDS with cut-off a level of -1.7 (which selected 102 of $350=29 \%$ ) we found 63 true positive, 14 false negative, 234 true negative, and 39 false positive. Using FFL/AC ratio with a cut-off level of 21.3 (which selected 105 of 350 $=30 \%$ ) to predict the infant being SGA (prevalence $=22 \%$ ) resulted in 33 true positive, 44 false negative, 201 true negative, and 72 false positive. The sensitivities, specificities and positive predictive values of FFL/AC ratio and ACSDS in predicting the infant being LGA or dysmature are presented in table II. 
Table II. Discriminant analysis with cut off levels on AC standard diviation score (AC-SDS) and FFL/AC ratio adjusted to select equal numbers of patients corresponding to about $1.5^{*}$ the prevalence resulted in the following accuracies for discriminating subgroups of infants

\begin{tabular}{|c|c|c|c|c|c|}
\hline & $\begin{array}{l}\text { Cutoff } \\
\text { level }\end{array}$ & $\begin{array}{l}\text { Proportion } \\
\text { selected }\end{array}$ & Sensitivity & Specificity & Predict. value \\
\hline \multicolumn{6}{|c|}{ Predicting the infant being SGA (prevalence $22.0 \%$ ): } \\
\hline $\begin{array}{l}\text { FFL/AC } \\
\text { AC-SDS }\end{array}$ & $\begin{array}{r}>21.3 \\
<-1.7\end{array}$ & $\begin{array}{l}30.0 \% \\
29.1 \%\end{array}$ & $\begin{array}{l}42.9 \% \\
81.8 \%\end{array}$ & $\begin{array}{l}82.0 \% \\
94.4 \%\end{array}$ & $\begin{array}{l}31.4 \% \\
61.8 \%\end{array}$ \\
\hline \multicolumn{6}{|c|}{ Predicting the infant being dysmature (prevalence $10.3 \%$ ): } \\
\hline $\begin{array}{l}\text { FFL/AC } \\
\text { AC-SDS }\end{array}$ & $\begin{array}{r}>22.1 \\
<-2.3\end{array}$ & $\begin{array}{l}16.9 \% \\
17.4 \%\end{array}$ & $\begin{array}{l}33.3 \% \\
41.7 \%\end{array}$ & $\begin{array}{l}91.8 \% \\
92.7 \%\end{array}$ & $\begin{array}{l}20.3 \% \\
24.6 \%\end{array}$ \\
\hline
\end{tabular}

In the 255 infants where an earlier measurement of $\mathrm{AC}$ and FFL/AC ratio could be included the mean interval between the two examinations were 46 days (range $28-57$ days). The correlation between the difference between the two ratios and the deviation of BW from normal was slighlty weaker than between the difference in AC-SDS and the BW deviation (delta-FFL/AC ratio: correlation coefficient $=-0.29, \mathrm{R}$ squared $=8.3 \%, \mathrm{p}<0.001$; delta-AC: correlation coefficient $=0.34$, R-squared $=11.7 \%$, $\mathrm{p}<0.001)$. No significant correlation was found neither between the difference in FFL/AC ratio and the dysmaturity score at birth nor between the difference in AC-SDS and the dysmaturity score.

\section{Discussion}

This patient material included a consecutive group with risk pregnancies - as demonstrated by the high prevalence of SGA infants $(22 \%)$. Our results on FFL/AC ratio confirm the observation of HADLOCK et al. [4] that this ratio is constant from 21 weeks of gestation to term. Furthermore we found an even more pronounced intra-individual constancy in normal pregnancies.

In the comparison between two methods for sonographical prediction of fetal malnutrition we found $\mathrm{AC}$ measurement far better correlated to the neonatal signs of fetal wastage than the FFL/ AC ratio. Using FFL/AC ratio with a cut-off level which selected $30 \%$ of the study population to predict BW below 10th percentile we found only $42.9 \%$ true positive whereas $68.6 \%$ were false positive. This contrasts to the results presented by HADLOCK et al. [4] who found $63.3 \%$ true positive and $36.7 \%$ false negative. Their patients were a selected group fo SGA compared to a normal group. Although significant correlations between FFL/AC ratio and PI and ST were found in this study, the low predictive power $(31.4 \%)$ indicates that FFL/AC ratio is not useful in detecting IUGR in risk pregnancies. Though the individual variation in FFL/AC ratio is small, a change in FFL/AC ratio between two measurements did not improve the prediction of IUGR.

AC predicted the infant being SGA well: $81.2 \%$ true positive and $38.2 \%$ false positive. Gross et al. [3] calculated the difference between abdominal diameter and BPD and found that with this parameter SGA was predicted in $68 \%$, whereas $23 \%$ were false positive. Divon et al. [2] calculated the AC growth rate from 2 measurements and found that they could predict $85 \%$ of SGA infants. The patient groups of Gross et al. [3] and Divon et al. [2] were selected groups with high prevalences of IUGR (about $40 \%$ ), and thus not comparable to our material. In our study calculation of the change in AC-SDS between two measurements did not improve the prediction of fetal growth deviation.

In conclusion AC deviation from normal for GA at a single occasion in a high risk population predicts fetal growth retardation with a precision equal to the best results referred in the literature. Estimation of FFL/AC ratio for this purpose can not be recommended, even for cases with unknown GA, because of an unacceptable high false positive rate. 


\begin{abstract}
The aim of this study was to compare the ability of abdominal circumference (AC) and fetal femur length/ abdominal circumference ratio (FFL/AC) measured by ultrasound within a period of 2 weeks before birth to predict low birth weight percentile and neonatal signs related to fetal malnutrition.

From longitudinal ultrasound measurements in 35 normal pregnancies reference data of $\mathrm{AC}$ and FFL was obtained. FFL/AC ratio was constant from 21 weeks until term (mean 20.9, SD 1.2) (figure 1).

In 350 risk pregnancies $\mathrm{AC}$ standard deviation score (AC-SDS) correlated far better than FFL/AC ratio with the deviation of birth weight from normal (figure 3). Furthermore AC-SDS correlated better with ponderal index (PI) and skinfold thickness (ST) than did
\end{abstract}

FFL/AC ratio. Using cut-off levels on AC-SDS and FFL/AC ratio, which selected about $30 \%$ of the population, the sensitivity of AC-SDS in predicting the infant being LGA was $81.8 \%$ versus $42.9 \%$ using FFL/ $\mathrm{AC}$ ratio (table II). The prediction of the infant being SGA was not improved when the change in AC-SDS or FFL/AC over the last 6-8 weeks of pregnancy was considered.

We conclude that AC-SDS correlates well with birth weight deviation and predicts the infant being SGA with a precision equal to the best results reported in the literature, and that FFL/AC ratio is unreliable even when GA is not known because of a high false positive rate.

Keywords: Fetal biometry, fetal growth, intrauterine growth retardation, small-for-gestational age.

\section{Zusammenfassung}

Fetaler Bauchumfang und Verhältmis von Femurlänge zu Bauchumfang als Parameter für Mangelernährung bei Risikoschwangerschaften

In der vorliegenden Studie haben wir die Aussagekraft von zwei biometrischen Parametern, Bauchumfang (AC) und Verhältnis von Femurlänge zu Bauchumfang (FFL/AC), miteinander verglichen. Innerhalb von zwei Wochen ante partum wurden sonographische Messungen durchgeführt und ausgewertet, ob ein niedriges Geburtsgewicht bzw. andere Hinweise auf eine fetale Mangelernährung vorhergesagt werden konnten.

In Longitudinalstudien wurden bei 35 unkomplizierten Schwangerschaften Referenzdaten von AC und FFL aufgestellt. Die FFL/AC-Ratio war von der 21. Schwangerschaftswoche bis zum Termin konstant (Mittelwert 20.9, Standardabweichung 1.9; Abb. 1).

Bei 350 Risikoschwangerschaften korrelierte der ACStandardabweichung-Score (AC-SDS) viel besser mit einer Abweichung vom normalen Geburtsgewicht als die FFL/AC-Ratio. Darüberhinaus war auch die Kor- relation mit dem Gewichtsindex (PI) und der Hautfaltendicke (ST) besser als bei der FFL/AC-Ratio. Bei Cut-off-Punkten für die AC-SDS und die FFL/ACRatio, mit denen um 30\% der Population erfaßt werden, lag die Sensitivität von AC-SDS, ein Kind mit niedrigem Geburtsgewicht (LGA) vorauszusagen bei $81,8 \%$ versus $42,9 \%$ bei Anwendung der FFL/ACRatio (Tab. II). Dabei wurde die Sensitivität nicht verbessert, wenn eine Änderung der AC-SDS oder FFL/AC-Ratio in den letzten 6-8 Schwangerschaftswochen berücksichtigt wurde.

Wir meinen, daß die AC-SDS gut mit dem Geburtsgewicht bzw. Abweichungen davon korreliert und ein Kind mit einem für das Gestationsalter zu niedrigen Geburtsgewicht mit einer Genauigkeit voraussagt, wie sie besser in der Literatur nicht beschrieben ist. Die FFL/AC-Ratio dagegen ist wegen einer hoch falsch positiven Rate nicht geeignet, gerade wenn das Gestationsalter nicht bekannt ist.

Schlüsselwörter: Fetale Biometrie, fetales Wachstum, intrauterine Wachstumsretardierung, Small-for-date.

\section{Résumé}

La circonférence abdominale fotale prédit mieux la malnutrition fetale au cours des grossesses à risque que le ratio longueur fémorale fetale/circonférence abdominale Le but de cette étude est de comparer la capacité de la circonférence abdominale (CA) et du ratio longueur fémorale fœtale/circonférence abdominale (LFF/CA) mesurés par échographie au cours des deux demaines précédant la naissance pour prédire les faibles percentiles de poids de naissance et les signes néonataux en rapport avec une malnutrition fœtale.

On a obtenu à partir des mesures échographiques longitudinales au cours de 35 grossesses normales les données de référence de la CA et de la LFF. Le ratio
LFF/CA est constant de 21 semaines jusqu'au terme (moyenne 20,9; DS = 1,2) (figure 1).

Au cours de 350 grossesses à risque le score de déviation standard de la CA (CA-DSS) est mieux corrélé que le ratio $\mathrm{LFF} / \mathrm{CA}$ avec la déviation du poids de naissance par rapport à la normale (figure 3). En outre, le CA-DSS est mieux corrélé avec l'index pondéral (IP) et l'épaisseur du pli cutané (ST) sque le ratio LFF/CA. En se servant de niveaux sur le CA-DSS et le ratio LFF/CA qui sélectionnent environ $30 \%$ de la population, la densibilité du CA-DSS pour prédire les enfants hypotrophes est de $81,8 \%$ contre $42,9 \%$ en se servant du ratio LFF/CA (tableau II). La prédiction 
des enfants hypotrophes n'est pas améliorée lorsque l'on considère les modifications du CA/DSS ou du LFF/CA au cours des $6-8$ dernières semaines de grossesse.

Nous en concluons que le CA/DSS est bien corrélé avec la déviation du poids de naissance et prédit les enfants hypotrophes avec une précision équivalente aux meilleurs résultats rapportés dans la littérature, et que le ratio LFF/CA n'est pas fiable même quand l'âge gestationnel n'est pas connu en raison du taux de faux positifs élevé.

Mots-clés: Biométrie fotale, croissance fœtale, retard de croissance intra-utérin, hypotrophie.

Acknowledgements: The study was supported by grants from 'Dronning Louises Børnehospitals Forskningsfond' (17/85 and 16/86) and 'Lundbeckfonden' (147/88).

\section{References}

[1] Brans YW, JE Sumners, HS DWECK, G CASSADY: A noninvasive approach to body composition in the neonate: Dynamic skinfold measurements. Pediatr Res 8 (1974) 215

[2] Divon MY, PF Chamberlain, L Sipos, FA ManNING, LD PLATT: Identification of small for gestational age fetus with the use of gestational ageindependent indices fo fetal growth. Am J Obstet Gynecol 155 (1986) 1197

[3] Gross BH, PW Callen, RA Filly: The relationship of fetal transverse body diameter and biparietal diameter in the diagnosis of intrauterine growth retardation. J Ultrasound Med 1 (1982) 361

[4] Hadlock FP, RL Deter, RB HaRrist, E ROECKER, SK PARK: A date-independent predictor of intrauterine growth retardation: femur length/ abdominal circumference ratio. AJR 141 (1983) 979

[5] Larsen T, S Petersen, G Greisen, J Falck LarSEN: Normal fetal growth evaluated by longitudinal ultrasound measurements. Early Hum Dev, to be published

[6] Larsen T, S Petersen, G Greisen, J Falck LarSEN: Detection of light for gestational age (LGA) by use of ultrasound screening in a randomized controlled study of 1000 risk patients. To be published.
[7] OUNSTED MK, VA MOAR, A SCOTT: Children of deviant birthweight at the age of seven years: health, handicap, size and developmental status. Early Hum Dev 9 (1984) 323

[8] Persson P-H: Personal communication

[9] Petersen S, A Gotfredsen, FU Knudsen: Lean body mass in small for gestational age and appropriate for gestational age infants. J Pediatr 113 (1988) 886

[10] RaNTAKallio P: A 14-year follow-up of children with normal and abnormal birth weight for their gestational age. Acta Paediatr Scand 74 (1985) 62

[11] WALTHER FJ; LHJ RAMAEKERS: The ponderal index as a measure of the nutritional status at birth and its relation to some aspects of neonatal morbidity. J Perinat Med 10 (1982) 42

[12] Weile B, N Bach-Mortensen, B Peitersen: Caliper skinfold measurements in newborns: Analysis of a method. Biol Neonate 50 (1986) 19

Received October 12, 1989. Accepted October 16, 1989.

Sten Petersen, M. D.

Department of Neonatology

Rigshospitalet

DK-2100 Copenhagen $\varnothing$

Denmark 